\title{
PSEUDOEKSFOLIACINIO SINDROMO PAPLITIMAS, JO POKYČIAI IR SĄSAJOS SU GLAUKOMA KAUNO MIESTO GYVENTOJŲ POPULIACIJOJE
}

\author{
Ugnẻ Rumelaitiené ${ }^{1}$, Martynas Špečkauskas ${ }^{1}$, Abdonas Tamošiūnas², \\ Ričardas Radišauskas ${ }^{2,3}$, Dalia Žaliūniené ${ }^{1}$ \\ ${ }^{1}$ Lietuvos sveikatos moksly universiteto Akiu ligu klinika, \\ ${ }^{2}$ Lietuvos sveikatos mokslu universiteto Kardiologijos institutas, \\ ${ }^{3}$ Lietuvos sveikatos moksly universiteto Aplinkos ir darbo medicinos katedra
}

Raktažodžiai: pseudoeksfoliacinis sindromas (PS), PS paplitimas, glaukoma.
Santrauka
Tikslas - išanalizuoti sergančiųjų pseudoeksfoliaciniu sindromu (PS) paplitimą, jo pokyčius Kauno miesto gyventojų populiacijoje ir sąsajas su glaukoma bei glau- komos įtarimu.
Metodika. Pakartotinio tyrimo metu (2016 m.) tirti 631 Kauno miesto gyventojas. Amžius - 55-83 metai. At- liktas nuodugnus oftalmologinis tyrimas (1262 akys): geriausias koreguotas regèjimo aštrumas, pachimetrija, biomikroskopija, akispūdis (IOS), N-30-F akipločio tyrimas, tinklainès optinè koherentinè tomografija, po medikamentinès midriazès matuotas vyzdžio diametras, fotografuotas akies dugnas, iš akies dugno nuotraukų vertintas regos nervo disko ir ekskavacijos diametrų santykis vertikaliame meridiane (CDR), PS nustatomas biomikroskopuojant, pseudoeksfoliacinei medžiagai esant ant akies priekinio segmento struktūrų.
Rezultatai. Tirtoje imtyje PS nustatytas 216 tiriamujuc ir 415 nenustatytas PS (Ne-PS), PS paplitimas-34,2 procento. Didžiausias PS paplitimas 45,3 proc. nu- statytas vyriausioje (76-83 m.) tiriamujų amžiaus gru- pejje, nepriklausomai nuo lyties. PS dažnis tarp lyčių nesiskyre: vyrams buvo 35,6 proc., moterims $-33,4$ proc. $(\mathrm{p}>0,05)$. Tiriamoje imtyje (1262 akių) nusta- tyta 113 (9,1 proc.) glaukomos atvejų, iš jų $63(6,8$ proc.) Ne-PS grupejje vs. 50 (15,7 proc.) PS grupejje (p $<0,001)$. Medikamentinèje midriazèje vyzdžio diame- tras buvo statistiškai reikšmingai mažesnis PS grupejje, lyginant su Ne-PS grupe (5,1 ir 6,0 mm atitinkamai (p $<0,001)$ ). Sergančių glaukoma PS ir Ne-PS grupèse

akispūdis reikšmingai nesiskyrè (16,0 ir 15,5 mmHg atitinkamai; $p>0,05$ ).

Išvados. Nustatytas PS tolimesnis plitimas tirtame kontingente ir ypač vyresnio amžiaus grupeje. Per 10 metų PS padaugèjo 3 kartus. Glaukoma du kartus dažniau nustatyta esant PS. Tiriamoje imtyje (1262 akių) nustatyta 113 (9,1 proc.) glaukomos atvejų, iš jų 63 (6,8 proc.) Ne-PS grupejje vs. 50 (15,7 proc.) PS grupeje. Per 10 metų atsirado 80 naujų GL atvejų. Nustatyta, kad sergančiujų glaukoma PS pogrupyje, palyginus su Ne-PS pogrupiu, pasiekta statistiškai reikšmingai mažesnè medikamentinè midriazè sergančių glaukoma PS pogrupyje (5,1 ir 6,0 $\mathrm{mm}$ atitinkamai).

\section{İvadas}

Pseudoeksfoliacinis sindromas (PS) yra su amžiumi susijęs tarpląstelinès matricos sutrikimas, kuriam esant akies priekinio segmento audiniuose gaminama ir kaupiama patologiné fibrilinè pseudoeksfoliaciné medžiaga (PM) [1]. PM išskiriama lęšiuko preekvatoriniame epitelyje, ragenos endotelyje, kraujagyslių endotelio ląstelèse, krumplyno epitelyje, trabekulų endotelyje ir rainelèje $[1,2]$. Manoma, kad PS yra globali patologija, pažeidžianti apie 60-70 milijonų žmonių visame pasaulyje [3]. Pasaulyje PS nustatomas $0,2-30,0$ proc. žmonių, vyresnių nei 60 metų [4-6]. Labiausiai PS paplitęs šiaurinèse šalyse [7-9]: Rusijoje 30 proc. (vyresniems nei $70 \mathrm{~m}$.), Islandijoje - 40,6 proc. (vyresniems nei $80 \mathrm{~m}$.) [9], Švedijoje net 61 proc. (vyresniems nei $87 \mathrm{~m}$.) [10]. Lietuvoje 2006-2008 metų tyrimo duomenimis PS paplitimas 65-72 metų amžiaus asmenims yra 23,7 procento [11].

Pirmasis $1917 \mathrm{~m}$. PM aprašè suomių oftalmologas John G. Lindberg (1884-1973). Savo disertaciniame darbe jis nagrinèjo pilkšvų depozitų atsidèjimą ant rainelès vyzdinio 
krašto, kurią pastebejjo naudodamasis plyšine lempa - biomikroskopu, paties sukonstruotu pagal Nobelio premijos laureato Allvar Gullstrand (1911 m.) išleistą monografiją. Tyrejas nustatè, kad naujasis fenomenas yra vienodai paplitęs sergantiems ir nesergantiems katarakta, vyresniems nei 55 metu žmonèms. Paplitimas didejja, didejjant amžiui, o sergantiems glaukoma (GL) jis nustatomas net 50 proc. atvejų [3,12]. PM nusèda akies priekiniame segmente. Dèl trabekulinio tinklo užsikimšimo sutrinka akies skysčio nutekejimas, kyla intraokulinis spaudimas (IOS) [13].

Pasaulyje 40-80 metų amžiaus žmonių populiacijoje GL paplitimas siekia apie 3,54 procento. 2013 metais GL sirgo 64,3 milijono 40-80 metų žmonių, o iki 2040 metų šis skaičius turètų išaugti iki $111,8 \mathrm{mln}$. [14]. Pasaulio sveikatos organizacijos duomenimis, GL yra pagrindinè negrižtamo aklumo priežastis pasaulyje, apie 5,2 milijono žmonių apako dèl GL. PS paplitęs visame pasaulyje ir yra dažniausia atviro kampo GL priežastis $[3,4]$. C. Ekström teigia, kad pseudoeksfoliacijos 9,8 karto didina riziką susirgti GL, o kartu esant padidejusiam IOS - net iki 67 kartų [15,16].-

PM atsideda visame priekiniame akies segmente. Rainelè judèdama trinasi ị lęšiuko priekinę kapsulę ir Zin'o saitus nutrina PM, kuri nusèda trabekuliniame tinkle. Priekinè lęšiuko kapsulè, ant kurios atsidèjusi PM, veikia kaip švitrinis popierius. Rainelei trinantis i PM, atsipalaiduoja rainelès pigmentas, kuris atsideda priekiniame akies segmente ir ypač - filtracinèje zonoje, priekinès kameros kampe. Trabekulinis tinklas tampa pigmentuotas dẻl nusėdusio pigmento. Dèl šių pakitimų sutrinka skysčio nutekejjimas priekiniame akies segmente. H. Forsius teigè, kad nustačius PM ant rainelès ir lęšiuko priekinès kapsulès pirminès atviro kampo glaukomos (PAKG) eiga gali būti sunkesnè [17].

Kaimyninèse Europos šalyse nèra PS paplitimo ir jo sąsajų su kitomis akių ligomis tyrimų. Estijoje atlikti du momentiniai PS paplitimo tyrimai. PS buvo nustatomas 305 tiriamiesiems, atvykusiems kataraktos operacijai ir 424 atsitiktine tvarka kviestiems tiriamiesiems [18]. Latvijoje buvo atliktas mažos imties (84 tiriamųjų) momentinis tyrimas, panirusio lęšiuko kataraktos pašalinimo operacijos baigties vertinimui [19]. Abiejų tyrimų metodika skyrèsi nuo mūsų tyrimo metodikos.

Tyrimo tikslas - išanalizuoti sergančiujų pseudoeksfoliaciniu sindromu paplitimą Kauno miesto gyventojų populiacijoje ir sąsajas su GL bei GL įtarimu.

\section{Tyrimo medžiaga ir metodai}

Po 10 metų pakartotiniame stebejjimo tyrime 2016-2017 m. dalyvavo $68655-83 \mathrm{~m}$. amžiaus Kauno miesto gyventojai (atsako dažnis 66,4 proc. nuo pradinio dalyvių skaičiaus, 78,9 proc. gyvų likusių dalyvių). 347 dalyviai negričzo ị ty- rimą, nes mirè, išvyko iš šalies ar atsisakè dalyvauti [20]. Pradinis tyrimas atliktas 2006-2008 m. LSMUL Akių ligų klinikoje doktoranto Martyno Špečkausko [11,21,22]. ŠIs tyrimas yra tarptautinio HAPIEE (angl. Health, Alcohol and Psychosocial Factors in Eastern Europe) tyrimo dalis [23], buvo įtrauktas ị E3 konsorciumą [24]. Tyrimas atliktas gavus Kauno regioninio biomedicininių tyrimų etikos komiteto pritarimą, protokolo Nr. PI-09/2005.

Tiriamujų kontingentas. Nustatyti įtraukimo kriterijai į tyrimą (neoperuotos akys arba kataraktos pašalinimo operacija, atlikta tik vienoje tiriamojo akyje) ir atmetimo kriterijai (kataraktos pašalinimo operacija atlikta abiejose tiriamojo akyse). I pakartotini tyrimą atvyko 686 tiriamieji, tačiau dèl atliktų oftalmologinių operacijų pagal nustatytus kriterijus ị tyrimą neįtraukti 55 tiriamujų duomenys. Iš viso ị pakartotini tyrimą buvo ịtrauktas 631 dalyvis. Visi tiriamieji perskaité, suprato ir pasirašè informuoto asmens sutikimo formą. Užpildyti anketiniai duomenys: anamnezè apie oftalmologines ligas ir naudojamus vaistus, akių operacijas. Oftalmologiškai ištirtos 1262 akys.

Oftalmologinis tyrimas. Atliktas nuodugnus oftalmologinis tyrimas pagal standartini protokolą ir tą pačią metodologiją, kaip ir pirminio tyrimo metu: vertintas geriausias koreguotas regejjimo aštrumas LogMar optotipų lentele [25], pachimetrija (centrinis ragenos storis, CRS), biomikroskopija, akispūdis matuotas aplanacinès tonometrijos būdu Goldmano tonometru [26], regos laukas (akiplotis) vertintas atliekant dažnių dubliavimo perimetriją (angl. Frequency doubling perimetry - FDT), N-30-F akipločio tyrimas (vertinti akipločio pakitimai viršutiniame ir apatiniame puslaukiuose, buvo apskaičiuotas bendras nuokrypis viršutinio ir apatinio (BNV/BNA) puslaukių atskirai $(\mathrm{dB})$ (sudejus visus taškus ir padalinus iš jų skaičiaus), tinklainès optinès koherentinès tomografijos tyrimas - tinklainès nervinių skaidulų sluoksnis (TNSS), medikamentinè midriazė sukelta ciklopentolato 1 proc. tirpalu, po medikamentinès midriazès matuotas vyzdžio diametras, akies dugno nuotrauka atlikta centruojant ị centrinę tinklainès duobutę (lot. Foveola centralis) su Canon CF-60Uvi (Canon Medical Systems, JAV) aparatu, iš dugno nuotraukų vertintas regos nervo disko (RND) ekskavacijos ir RND diametro santykis vertikaliame meridiane (angl. Vertical cup/disk ratio - CDR).

PS buvimas vertintas diagnostinèje midriazèje biomikroskopuojant plyšine lempa. PS nustatytas, jeigu buvo pastebètos pilkšvo atspalvio, plèvelès pavidalo PM ant lęšiuko priekinès kapsulès (centrinis diskas/arba pilna arba dalinè periferine juosta), pilkšvi PM depozitai ant vyzdinio rainelès krašto ar ragenos užpakalinio paviršiaus. PS ịtarimu buvo laikyti atvejai, kai nebuvo stebėta anksčiau minètų pakitimų ir kai buvo stebetas apnašas kaip šerkšnas ar migla 
ant lęšiuko priekinès kapsulès (lęšiuko priekinès kapsulès paviršius atrode matinis). Jeigu PS nustatytas bent vienoje akyje, tiriamasis priskirtas PS grupei.

Glaukomos ar jos įtarimo nustatymas. GL diagnozė buvo patvirtinta pagal surinktą anamnezę: pacientas žinojo, kad serga GL; žinojo, kokius antiglaukominius akių lašus naudojo; žinojo, kad buvo atlikta antiglaukominè operacija.

Atmetus sergančius GL (atitiko anksčiau išvardintus kriterijus), pagal tyrimų rezultatus atrinktos akys, įtariamos GL: 1) remiantis dažnių dubliavimo perimetrijos (angl. Frequency doubling perimetry - FDT) klasifikavimo sistema pagal FDT N-30-F akipločio tyrimą, tiriamasis buvo priskirtas prie nesergančių arba sergančių GL ir nustatyta GL stadija [27]. Tie akipločio tyrimai, kurių MD ir PSD vertès nesutapo, buvo vertinami individualiai, atrinkus tyrimus su glaukominiais akipločio pakitimais; 2) jeigu IOS $\geq 21 \mathrm{mmHg}$ (perskaičiuotu pagal centrinį ragenos storị) [28]; 3) jeigu TNSS buvo žemiau normos ir CDR $>0,5$ ir (ar) CDR asimetrija tarp akiu $>0,2$ [26,29]; 4) jeigu tiriamojo IOS buvo $<21 \mathrm{mmHg}$ ir jis atitiko visus aukščiau išvardytus kriterijus.

Statistinė duomenų analizė atlikta naudojant statistinès analizès programinị paketą (IBM SPSS Version 27.0 software). Statistinio reikšmingumo vertinimui pasirinktas

1 lentelè. PS pasiskirstymas tiriamujjų imtyje pagal lytị ir amžių.

\begin{tabular}{|c|c|c|c|c|}
\hline Tiriamieji & $\begin{array}{l}\text { Nenustatytas } \\
\text { PS, n ( proc.) }\end{array}$ & $\begin{array}{c}\text { Nustatytas PS, } \\
\text { n ( proc.) }\end{array}$ & $\begin{array}{l}\text { Iš viso, } \\
\text { n ( proc.) }\end{array}$ & p reikšmė \\
\hline Visi tiriamieji & $415(65,8)$ & $216(34,2)$ & $631(100,0)$ & 0,581 \\
\hline \multicolumn{5}{|l|}{ Lytis } \\
\hline Vyrai & $154(64,4)$ & $85(35,6)$ & $239(100,0)$ & \multirow[t]{2}{*}{0,581} \\
\hline Moterys & $261(66,6)$ & $131(33,4)$ & $392(100.0)$ & \\
\hline \multicolumn{5}{|l|}{ Amžius (m.) } \\
\hline $55-65$ & $158(38,1)^{* 1}$ & $48(22,2)^{*}$ & $206(100,0)$ & \multirow{3}{*}{$\begin{array}{c}\mathbf{0 , 0 0 1} \\
* \mathbf{p}<0,05\end{array}$} \\
\hline $66-75$ & $148(35,7)^{2}$ & $70(32,4)$ & $218(100,0)$ & \\
\hline $76-83$ & $109(26,2)^{* 3}$ & $98(45,4)^{*}$ & $207(100,0)$ & \\
\hline \multicolumn{5}{|l|}{ Vyrams } \\
\hline $55-65$ & $58(37,7)^{* *}$ & $18(21,2)^{* *}$ & $76(31,8)$ & \multirow{3}{*}{$\begin{array}{l}\mathbf{0 , 0 0 1} \\
* * \mathbf{p}< \\
\mathbf{0 , 0 0 1}\end{array}$} \\
\hline $66-75$ & $54(35$, & $23(2$ & $77(32,2)$ & \\
\hline $76-83$ & $42(27,3)^{* *}$ & $44(51,8)^{* *}$ & $86(36,0)$ & \\
\hline \multicolumn{5}{|l|}{ Moterims } \\
\hline $55-65$ & $100(38,3)^{* * * *}$ & $30(22,9)^{* * *}$ & $130(33,2)$ & \multirow{3}{*}{$\begin{array}{c}\mathbf{0 , 0 0 1} \\
* * * \mathbf{p}< \\
\mathbf{0 , 0 0 1}\end{array}$} \\
\hline $66-75$ & $94(36,0)$ & $47(35,9)$ & $141(36,0)$ & \\
\hline $76-83$ & $67(25,7) * * *$ & $54(41,2)^{* * *}$ & $121(30,9)$ & \\
\hline Vidurkis $( \pm \mathrm{SN})$ & $68,70(8,16)$ & $73,01(7,97)$ & & 0,001 \\
\hline Mediana & 68,0 & 74,0 & & 0,001 \\
\hline \multicolumn{5}{|c|}{ 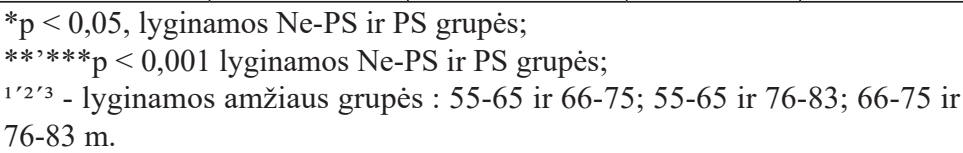 } \\
\hline
\end{tabular}

reikšmingumo lygmuo, $p<0,05$. Duomenų normalumas tikrintas naudojant Kolmogorov-Smirnov testą. Kai duomenys buvo nenormalūs, skaičiuotos medianos ir interkvartiliai (IQR). Naudotas Mann-Whitney U testas lyginti pastovius duomenis. Kategoriniai kintamieji lyginti taikant Chi square $\left(\chi^{2}\right)$ ar Fisher exact 2-sided testus. Kokybiniams požymiams, linijinei tendencijai patvirtinti naudotas $\chi^{2}$ linear-by-linear asociacijų testas. Kokybinių požymių skirstinių palyginimui susietose (priklausomose) imtyse naudotas McNemar testas.

\section{Tyrimo rezultatai ir jų aptarimas}

I tyrimą buvo įtrauktas 631 tiriamasis, tirtos 1262 akys. PS buvo vertinamas 1262 akyse. PS bent vienoje akyje buvo nustatytas 216 tiriamujų - 141 dešinejje ir 185 kaireje akyje. PS dažnis buvo 34,2 proc., iš jų 85 (39,4 proc.) vyrams ir 131 (60,6 proc.) moterims. PS dažnio pasiskirstymas tarp lyčių nesiskyrè: vyrų 35,6 proc., moterų 33,4 proc. $(p>0,05)$ (1 lentelè).

Amžiaus vidurkis buvo statistiškai reikšmingai didesnis PS grupejje 73,01 $\pm 7,97$, lyginant su Ne- PS grupe $68,70 \pm 8,16$ $(\mathrm{p}<0,001)$. Nustatyta, kad statistiškai reikšmingai PS daugèja su amžiumi: 22,2 proc. 55-65 amžiaus grupèje, 32,4 proc. 66-75 metų grupeje ir didžiausias paplitimas vyriausioje 76-83 metų amžiaus grupeje $-45,4$ proc. $(\mathrm{p}<0,001)$. Palyginus $55-65$ ir $66-75 ; 55-65$ ir 76-83; 66-75 ir 76-83 metų amžiaus grupes, tarp jų pasiektas statistinis reikšmingumas $(\mathrm{p}<$ 0,05) (1 lentelè).

PS dažnio didèjimas amžiaus poveikyje stebètas atskirai ịvertinus jị vyrams ir moterims ( $p$ $<0,001)$. PS pasiskirstymas pagal lytị didžiausias išliko vyriausioje amžiaus grupeje ir skirtumas buvo statistiškai reikšmingas: vyrams $-51,8$ proc., moterims $-41,2$ procento ( 1 lentelè ).

Tiriamoje imtyje nustatyta 113 (9,1 proc.) GL atvejų, 63 (6,8 proc.) Ne-PS grupeje vs. 50 (15,7 proc.) PS grupeje $(p<0,001)$. GL įtarimą nustatème 37 akims, Ne-PS grupejje 26 (2,8 proc.) ir PS grupeje 11 (3,4 proc.) (p>0,05). Tiriamajame kontingente 1095 akiai nebuvo nustatyta ar itarta GL (2 lentelè).

Sergančiųų GL grupèje GL PS pogrupyje IOS statistiškai nereikšmingai buvo didesnis (16,0 mmHg), lyginant su sergančiujų GL NePS pogrupiu $(15,5 \mathrm{mmHg} ; \mathrm{p}>0,05)$. CRS buvo mažesnis PS GL pogrupyje $515 \mu \mathrm{m}$ vs. Ne-PS GL pogrupiu $522 \mu \mathrm{m}(\mathrm{p}>0,05)$. TNSS bendrame, viršutiniame ir apatiniame segmentuose buvo sumažejęs PS GL pogrupyje, palyginus su Ne-PS GL pogrupiu (PS 82,0/87,0/80,0 vs. Ne- 
PS 89,0/87,5/90,5 $\mu \mathrm{m} ; \mathrm{p}>0,05)$. TNSS PS GL pogrupyje labiau sumažejęs buvo apatiniuose segmentuose. Koreliacijos tarp TNSS viršutinès ir apatinès dalies pokyčių bei akipločio viršutinio ir apatinio puslaukių pokyčių GL PS ir GL Ne-PS pogrupiuose nestebejome. GL pogrupiuose akipločio pakenkimo dydis nesiskyre viršutiniame ir apatiniame puslaukiuose $(p>0,05)$. PS GL pogrupyje geriausias koreguotas matymas buvo prastesnis 0,3 , lyginat su Ne-PS GL pogrupiu 0,2 (p $>0,05)$. PS GL pogrupyje vyzdžio diametras cikloplegijoje buvo statistiškai reikšmingai mažesnis (PS 5,10 vs. Ne-PS 6,0 mm) (3 lentelè.).

GL įtarimo grupeje statistiškai reikšmingo tyrimų duo- menų skirtumo tarp pogrupių nenustatėme. Šioje grupejje IOS stebetas didesnis GL įtarimo Ne-PS pogrupyje (17,0 $\mathrm{mmHg}$ ) lyginant su GL įtarimo PS pogrupiu $(14,0 \mathrm{mmHg})$. CRS buvo mažesnis GL įtarimo PS pogrupyje (Ne-PS 538 vs. PS $525 \mu \mathrm{m})$. TNSS GL ịtarimo grupeje buvo mažesnis Ne-PS GL įtarimo pogrupyje (Ne-PS $83,0 / 89,0 / 79,0$ vs. PS $92,5 / 93,0 / 92,0 \mu \mathrm{m})$. Geriausias koreguotas matymas buvo blogesnis GL įtarimo grupès Ne-PS pogrupyje (Ne-PS 0,3 vs. PS 0,2). Po midriatikų vyzdys mažiau plètèsi GL įtarimo PS pogrupyje (Ne-PS 6,5 vs. PS 6,0 mm). Akiplotis buvo labiau pakitęs viršutiniame puslaukyje GL ịtarimo Ne-PS pogrupyje ir koreliavo su TNSS pakitimais apatiniame segmente. Lygi-

2 lentelè. Glaukomos ir glaukomos įtarimo pasiskirstymas pagal PS imtyje.

\begin{tabular}{|c|c|c|c|c|}
\hline & $\begin{array}{c}\text { Nenustatytas PS, } \\
\text { n ( proc.) }\end{array}$ & $\begin{array}{c}\text { Nustatytas PS, } \\
\text { n ( proc.) }\end{array}$ & $\begin{array}{l}\text { Iš viso, } \\
\text { n ( proc.) }\end{array}$ & $\underset{\text { reikšmè }}{\mathbf{p}}$ \\
\hline Glaukoma sergantys & $63(6,8)^{*}$ & $50(15,7)^{*}$ & $113(9,1)$ & \multirow[b]{4}{*}{$\mathrm{p}<\mathbf{0 , 0 0 1}$} \\
\hline Glaukomos įtarimas & $26(2,8)$ & $11(3,4)$ & $37(3,0)$ & \\
\hline Glaukoma nesergantys & $837(90,4)^{*}$ & $258(80,9)^{*}$ & $1095(88,0)$ & \\
\hline Iš viso & $926(100,0)$ & $319(100,0)$ & $1245(100,0)^{* *}$ & \\
\hline \multicolumn{5}{|c|}{$\begin{array}{l}* \mathrm{p}<0,001 \text { lyginamos PS ir Ne-PS grupès; } \\
* * \text { akis laikyta kaip objektas; }\end{array}$} \\
\hline
\end{tabular}

3 lentelè. Oftalmologinių parametrų pasiskirstymas glaukomos ir PS grupėse.

\begin{tabular}{|c|c|c|c|c|c|c|}
\hline & \multicolumn{2}{|c|}{ Glaukoma sergantys } & \multicolumn{2}{|c|}{ Glaukomos įtarimas } & \multicolumn{2}{|c|}{ Glaukoma nesergantys } \\
\hline & nenustatytas PS & nustatytas PS & nenustatytas PS & nustatytas PS & nenustatytas PS & nustatytas PS \\
\hline & \multicolumn{6}{|c|}{ Mediana (O1-Q3) } \\
\hline IOS, mmHg & $15,5(14,0-17,0)$ & $\begin{array}{c}16,0(14,0- \\
18,0)\end{array}$ & $17,0(15,0-18,0)$ & $\begin{array}{c}14,0(13,4- \\
17,0)\end{array}$ & $15,0(14,0-16,3)$ & $15,0(14,0-17,0)$ \\
\hline CRS, $\mu \mathrm{m}$ & $522(494-556)$ & $515(488-545)$ & $538(518-556)$ & $525(504-544)$ & $532(511-554)$ & $533(510-557)$ \\
\hline CDR & $0,4(0,4-0,5)$ & $0,4(0,4-0,5)$ & $0,4(0,4-0,6)$ & $0,4(0,3-0,5)$ & $0,4(0,3-0,4)$ & $0,4(0,3-0,4)$ \\
\hline $\begin{array}{l}\text { TNSS ben- } \\
\text { dras, } \mu \mathrm{m}\end{array}$ & $89,0(66,5-103,5)$ & $\begin{array}{c}82,0(74,0- \\
94,0)\end{array}$ & $83,0(64,0-96,0)$ & $\begin{array}{c}92,50(79,0- \\
106,0)\end{array}$ & $\begin{array}{c}95,0(87,0- \\
104,0)^{*}\end{array}$ & $\begin{array}{c}93,0(84,0- \\
103,0)^{*}\end{array}$ \\
\hline $\begin{array}{l}\text { TNSS viršutinis, } \\
\mu \mathrm{m}\end{array}$ & $87,5(67,5-101,5)$ & $\begin{array}{c}87,0(71,0- \\
96,0)\end{array}$ & $89,0(70,0-96,0)$ & $\begin{array}{c}93,0(80,0- \\
111,0)\end{array}$ & $\begin{array}{c}98,0(88,0- \\
107,0)^{*}\end{array}$ & $\begin{array}{c}95,0(86,0- \\
104,0)^{*}\end{array}$ \\
\hline $\begin{array}{l}\text { TNSS apatinis, } \\
\mu \mathrm{m}\end{array}$ & $90,5(67,0-103,5)$ & $\begin{array}{c}80,0(67,0- \\
92,0)\end{array}$ & $79,0(63,0-96,0)$ & $\begin{array}{c}92,0(77,0- \\
101,0)\end{array}$ & $\begin{array}{c}92,0(84,0- \\
102,0)^{*}\end{array}$ & $\begin{array}{c}91,0(80,0- \\
100,0)^{*}\end{array}$ \\
\hline $\begin{array}{l}\text { Geriausias kore- } \\
\text { guotas matymas, } \\
\text { LogMar }\end{array}$ & $0,2(0,1-0,37)$ & $0,3(0,16-0,45)$ & $0,3(0,14-0,44)$ & $0,2(0,08-0,35)$ & $0,1(0,0-0,26)$ & $0,2(0,07-0,34)$ \\
\hline $\begin{array}{l}\text { Vyzdžio diame- } \\
\text { tras, mm }\end{array}$ & $6,0(5,5-7,0)^{*}$ & $5,10(4,8-5,5)^{*}$ & $6,5(6,0-7,0)$ & $6,0(5,8-6,0)$ & $7,0(6,0-7,0)^{*}$ & $6,0(5,5-6,3)^{*}$ \\
\hline $\mathrm{BNV}, \mathrm{dB}$ & $26,33(21,72-30,22)$ & $\begin{array}{c}25,95(21,72- \\
29,06) \\
\end{array}$ & $\begin{array}{c}18,06(13,44- \\
22,78) \\
\end{array}$ & $\begin{array}{c}21,78(17,5- \\
22,5) \\
\end{array}$ & $\begin{array}{c}28,33(25,11- \\
31,0)^{* *} \\
\end{array}$ & $\begin{array}{c}27,11(23,73- \\
30,0)^{* *} \\
\end{array}$ \\
\hline BNA, dB & $25,78(21,06-29,73)$ & $\begin{array}{c}25,89(20,67- \\
29,89)\end{array}$ & $\begin{array}{c}20,28(13,89- \\
23,78)\end{array}$ & $\begin{array}{c}20,22(16,61- \\
21,73)\end{array}$ & $\begin{array}{c}28,44(25,78- \\
31,0)^{* *}\end{array}$ & $\begin{array}{c}27,5(24,39- \\
30,44)^{* *}\end{array}$ \\
\hline
\end{tabular}


nant GL ịtarimo grupès pogrupius, Ne-PS pogrupyje labiau buvo pakenktas viršutinis akipločio puslaukis. PS pogrupyje labiau pakenktas buvo apatinis akipločio puslaukis, o NePS pogrupyje - viršutinis. GL įtarimo pogrupiuose CDR ir akipločio apatinio puslaukio duomenys nesiskyrè (3 lentelè).

GL nesergančių tiriamuju grupèje TNSS storis bendras, viršutiniame ir apatiniame segmentuose buvo statistiškai reikšmingai mažesnis PS pogrupyje, lyginant su Ne-PS pogrupiu (93,0/95,0/91,0 ir 95/98/92 $\mu \mathrm{m}$ atitinkamai). Geriausias koreguotas matymas buvo prastesnis GL nesergančiųu PS pogrupyje - 0,2, lyginant su Ne-PS grupe - 0,1 ( $p>0,05)$. Statistiškai reikšmingai medikamentinèje midriazèje vyzdys buvo mažesnio diametro PS pogrupyje (Ne-PS 7,0 vs. PS $6,0 \mathrm{~mm} ; \mathrm{p}<0,001)$. Akiplotis abiejuose puslaukiuose buvo reikšmingai labiau pakenktas GL nesergančių PS pogrupyje. Koreliacijos tarp TNSS ir akipločio puslaukių pakenkimo šioje grupeje nestebejjome. GL nesergančių pogrupiuose nesiskyrè IOS, CRS, CDR (3 lentelè).

Lietuvoje 2006 metų tyrimo (pradinio) duomenimis, PS dažnis buvo 10,3 procento [11]. Per 10 metų toje pačioje tiriamujjų imtyje (pakartotinis tyrimas) PS dažnis padidejo per 3 kartus, iki 34,2 proc. (55-83 metų tiriamiesiems). Estijoje PS paplitimas rastas 25,5-35,4 proc., kai tiriamujjų amžiaus vidurkis buvo 71,5 $\pm 8,6$ metų (amžius nuo 40 iki 93 metų). Jų tyrime PS dažnis taip pat didejjo su amžiumi nuo 17,6 proc. 50-59 metų amžiaus grupejje iki 38,6 proc. $80-89$ metu amžiaus grupejje. Estų tyrime PS dažniau nustatytas vyrams nei moterims, tik vyriausio amžiaus grupejje PS nustatyta daugiau moterims, negu vyrams [18,30]. Palyginimui mūsų tyrime nustatytas PS dažnio pasiskirstymas tarp lyčių reikšmingai nesiskyrè: vyrams 35,6 proc., moterims 33,4 proc. 66-75 metų amžiaus grupèje PS dažniau pasitaikè moterims, o vyriausio amžiaus (76-83 metu) grupejje - vyrams. Estų tyrime IOS buvo aukštesnis PS nei Ne-PS grupejje $(19,2 \pm 6,5$ vs. $17,1 \pm 3,8 \mathrm{mmHg} ; \mathrm{p}=0,006)$. GL buvo nustatyta $14,8-16,5$ proc., iš jų 35,7-54,4 proc. buvo nustatyta pseudoeksfoliacinè GL $[18,30]$. Mūsų tyrime nustatytas IOS buvo aukštesnis PS grupejje nei Ne-PS (16,0 vs. 15,0 mmHg; atmetus glaukomą), o GL grupes PS pogrupyje IOS taip pat buvo didesnis $(16,0$ $\mathrm{mmHg}$ ), lyginant su Ne-PS pogrupiu $(15,5 \mathrm{mmHg} ; \mathrm{p}>0,05)$. Mūsų tirtoje imtyje nustatyta 9,1 proc. (113) GL, iš jų 44,2 proc. atvejų nustatyta pseudoeksfoliacinè glaukoma.

Pasaulyje apie 20-25 proc. žmonių populiacijos nustatyta pseudoeksfoliacinė GL. Pacientai, sergantys pseudoeksfoliacine GL, yra vyresni, nei sergantieji PAKG [4]. Mūsų tyrime sergančiujų GL buvo 9,1 proc. (113 akių). PS grupèje GL sirgo 2 kartus daugiau tiriamujų (15,7 proc.). Per 10 metų atsirado 80 naujų GL atvejų, iš jų 42 Ne-PS grupeje ir 38 PS grupèje. Blue Mountain akių studijos duomenimis,
Australijoje, akyse su PS GL pasitaikė 8 kartus dažniau, pseudoeksfoliacine GL sirgo 14,2 proc. vyresni nei 48 metu žmonès [31]. Kitoje studijoje -Thessaloniki, šiaurinëje Graikijoje, vyresniems nei 60 metu asmenims daugiau GL atvejų nustatyta tarp sergančių PS (15,2 proc.), nei tarp nesergančiu PS (4,7 proc.) [32], o po 12 stebejimo metu 9 proc. PS tiriamujų išsivystė glaukoma [33]. Švedijoje PAKG paplitimas nustatytas 2,1 proc. (PI 0,8-4,3 proc.) 66 metų tiriamiesiems ir 25 proc. (PI 16-35 proc.) 87 metų tiriamiesiems. Po 21 stebejjimo metų nustatyti 32 nauji GL atvejai, iš jų 59 proc. buvo nustatytas PS [8]. Indijoje atliktoje Chennai studijoje po 6 stebejjimo metų tarp sergančių PS nustatyti 8 nauji GL atvejai [34].

Graikijoje atliktoje studijoje PS GL grupeje IOS buvo didesnis 17,9 mmHg nei Ne-PS glaukomos grupeje 15,5 mmHg $(p=0,0004)$ [33]. Mūsų tyrime taip pat aukštesnis IOS buvo PS grupejje, tačiau nustatytas mažesnis IOS skirtumas tarp grupių (Ne-PS 15,5 vs. PS 16,0 mmHg, p >0,05).

\section{Išvados}

1. 2016-2017 m. pakartotinio tyrimo metu (intervalas 10 m., 631 tiriamasis, 1262 akys) Kauno miesto gyventojams nustatytas didesnis PS paplitimas (216 tiriamujų, 34,2 proc.), lyginant su pirminio tyrimo (2006-2008 m.) duomenimis (10,3 proc.). Didžiausias PS paplitimas (45,3 proc.) nustatytas vyriausioje (76-83m.) tiriamujų amžiaus grupeje, nepriklausomai nuo lyties.

2. Pakartotinai ištyrus tiriamuosius (1262 akių), nustatyta 113 (9,1 proc.) glaukomos atvejų: 63(6,8 proc.) Ne-PS grupejje vs. 50 (15,7 proc.) PS grupèje. PS grupèje GL sirgo du kartus daugiau tiriamujų. Per 10 metų atsirado 80 naujų GL atvejų.

3. Nustatyta, kad sergančiųų glaukoma PS pogrupyje, palyginus su sergančių glaukoma Ne-PS pogrupiu, statistiškai reikšmingai pasiekta mažesnẻ medikamentinė midriazė sergančių glaukoma PS pogrupyje $(5,1$ ir $6,0 \mathrm{~mm}$ atitinkamai).

Finansavimas. Šis pakartotinis tyrimas finansuotas gavus Lietuvos mokslo tarybos ir Nacionalinès mokslų programos „Sveikas senejjimas" stipendiją (Nr. SEN-15028). HAPIEE tyrimas buvo paremtas gavus dotacijas iš „Sveikas pasitikèjimas“ (angl. Wellcome Trust; Nr. 064947/Z01/Z), Jungtiniu Amerikos Valstijų Nacionalinio senejjimo instituto (Nr. IR0I AG23522-01) ir MacArthur fondo (Sveikatos ir socialinių pokyčių tinklo), (angl. the MacArthur Foundation, Health and Social Upheaval Network).

Padėka. Labai dèkoju kolegoms iš Londono Moorfields akiu ligoninès Tunde Peto ir Morten Bøgelund Larsen už pagalba, rašant ṣ̨̌ staipsnị. 


\section{Literatūra}

1. Schlötzer-Schrehardt U, Naumann GOH. Ocular and Systemic Pseudoexfoliation Syndrome. Am J Ophthalmol 2006;141:921937. https://doi.org/10.1016/j.ajo.2006.01.047

2. Zenkel M, Schlötzer-Schrehardt U. The Composition of Exfoliation Material and the Cells Involved in Its Production. J Glaucoma 2014;23:S12-S14. https://doi.org/10.1097/IJG.0000000000000123

3. Nazarali S, Damji F, Damji KF. What have we learned about exfoliation syndrome since its discovery by john lindberg 100 years ago. Br J Ophthalmol 2018;102:1342-1350. https://doi.org/10.1136/bjophthalmol-2017-311321

4. Ritch R, Schlötzer-Schrehardt U. Exfoliation syndrome. Surv Ophthalmol 2001;45:45:265-315. https://doi.org/10.1016/S0039-6257(00)00196-X

5. Wang W, He M, Zhou M, Zhang X. Ocular pseudoexfoliation syndrome and vascular disease: A systematic review and metaanalysis. PLoS One 2014;9:1-7.

https://doi.org/10.1371/journal.pone.0092767

6. You QS, Xu L, Wang YX, Yang H, Ma K, Li JJ, et al. Pseudoexfoliation: normative data and associations: the Beijing eye study 2011. Ophthalmology 2013;120:1551-8. https://doi.org/10.1016/j.ophtha.2013.01.020

7. Forsius H, Forsman E, Fellman J, Eriksson AW. Exfoliation syndrome: frequency, gender distribution and association with climatically induced alterations of the cornea and conjunctiva. Acta Ophthalmol Scand 2002;80:478-84. https://doi.org/10.1034/j.1600-0420.2002.800504.x

8. Åström S, Lindén C. Incidence and prevalence of pseudoexfoliation and open-angle glaucoma in northern Sweden: I. Baseline report. Acta Ophthalmol Scand 2007;85:828-831. https://doi.org/10.1111/j.1600-0420.2007.00992.x

9. Arnarsson A, Damji KF, Sverrisson T, Sasaki H, Jonasson F. Pseudoexfoliation in the Reykjavik Eye Study: prevalence and related ophthalmological variables. Acta Ophthalmol Scand 2007; 85: 822-827.

https://doi.org/10.1111/j.1600-0420.2007.01051.x

10. Åström S, Stenlund H, Lindén C. Incidence and prevalence of pseudoexfoliations and open-angle glaucoma in northern Sweden: II. Results after 21 years of follow-up. Acta Ophthalmol Scand 2007; 85:832-837.

https://doi.org/10.1111/j.1600-0420.2007.00980.x

11. Špečkauskas M, Barzdžiukas V, Jašinskas V. Pseudoeksfoliacinio sindromo sindromo paplitimas ir jo sąsajos su glaukoma ir akių hipertenzija Lietuvos suaugusiuju populiacijoje. Medicina (B Aires) 2011;15:499-503.

12. Tarkkanen A, Kivelä T. John G. Lindberg and the discovery of exfoliation syndrome. Acta Ophthalmol Scand 2002; 80: 151-154.

https://doi.org/10.1034/j.1600-0420.2002.800206.x
13. Ritch R. Exfoliation syndrome and occludable angles. Trans Am Ophthalmol Soc 1994; 92: 845.

14. Tham YC, Li X, Wong TY, Quigley HA, Aung T, Cheng CY. Global prevalence of glaucoma and projections of glaucoma burden through 2040: A systematic review and meta-analysis. Ophthalmology 2014;121:2081-2090.

https://doi.org/10.1016/j.ophtha.2014.05.013

15. Ekström C, Alm A. Pseudoexfoliation as a risk factor for prevalent open-angle glaucoma. Acta Ophthalmol 2008;86:741-746. https://doi.org/10.1111/j.1755-3768.2008.01248.x

16. Ekström C. Incidence of open-angle glaucoma in central Sweden. Acta Ophthalmol 2008; 86: 747-754. https://doi.org/10.1111/j.1755-3768.2008.01244.x

17. Forsius H. Exfoliation syndrome in various ethnic populations. Acta Ophthalmol Suppl (Oxf) 1988;184:71-85. https://doi.org/10.1111/j.1755-3768.1988.tb02633.x

18. Kaljurand K, Puska P. Exfoliation syndrome in Estonian patients scheduled for cataract surgery. Acta Ophthalmol Scand 2004;82:259-63. https://doi.org/10.1111/j.1600-0420.2004.00256.x

19. Vanags Juris. Changes to the Anterior Capsular Opening of Human Lens after Cataract Surgery in Patients with Subluxated Lenses. Ph.D Thesis. Riga, Latvia.

https://www.rsu.lv/en/dissertations

20. Rumelaitienė U, Žaliūnienė D, Špečkauskas M, Tamošiūnas A, Radišauskas R, Jusevičiūtė E, et al. Link of ocular pseudoexfoliation syndrome and vascular system changes: results from 10-year follow-up study. Int Ophthalmol.

https://doi.org/10.1007/s10792-019-01262-x

21. Špečkauskas M, Tamošiūnas A, Jašinskas V. Association of ocular pseudoexfoliation syndrome with ischaemic heart disease, arterial hypertension and diabetes mellitus. Acta Ophthalmol 2012; 90: e470-e475.

https://doi.org/10.1111/j.1755-3768.2012.02439.x

22. Špečkauskas M. Pseudoeksfoliacinio sindromo paplitimas ir jo pasireiškimo ypatumai, esant akių bei širdies ir kraujagyslių sistemos pokyčiams. Daktaro disertacija, 2012. https://www. 1smuni.1t/cris/bitstream/20.500.12512/12473/2/Speckauskas_disertacija.pdf

23. Peasey A, Bobak M, Kubinova R, Malyutina S, Pajak A, Tamosiunas A, et al. Determinants of cardiovascular disease and other non-communicable diseases in Central and Eastern Europe: rationale and design of the HAPIEE study. BMC Public Health 2006; 6:1-10.

https://doi.org/10.1186/1471-2458-6-255

24. Delcourt C, Korobelnik JF, Buitendijk GHS, Foster PJ, Hammond CJ, Piermarocchi S, et al. Ophthalmic epidemiology in Europe: the "European Eye Epidemiology" (E3) consortium. Eur J Epidemiol 2016; 31:197-210. https://doi.org/10.1007/s10654-015-0098-2

25. Holladay JT. Proper method for calculating average visual 
acuity. J Refract Surg 1997;13:388-391.

https://doi.org/10.3928/1081-597X-19970701-16

26. Roger H. Terminology and guidelines for glaucoma 4th Edition. Italy. Epub ahead of print 2017.

https://doi.org/10.1136/bjophthalmol-2016-EGSguideline.001

27. Brusini P, Tosoni C. Staging of Functional Damage in Glaucoma Using Frequency Doubling Technology. 2003.

https://doi.org/10.1097/00061198-200310000-00004

28. Ehlers N, Bramsen T, Sperling S. Applanation tonometry and central corneal thickness. Acta Ophthalmol 1975;53:34-43.

https://doi.org/10.1111/j.1755-3768.1975.tb01135.x

29. Janulevičienė I, Kuzmienė L. Glaukomų raidos struktūriniai ir funkciniai savitumui. Kaunas: LSMU Leidybos namai, 2013.

30. Kaljurand K, Teesalu P. Prevalence of exfoliation syndrome in Estonia. Eur J Ophthalmol 2010; 20:1012-1017. https://doi.org/10.1177/112067211002000622

31. Mitchell P, Wang JJ, Hourihan F. The relationship between glaucoma and pseudoexfoliation: the Blue Mountains Eye Study. Arch Ophthalmol (Chicago, Ill 1960) 1999; 117: 1319-24. https://doi.org/10.1001/archopht.117.10.1319

32. Topouzis F, Harris A, Wilson MR, Koskosas A, Founti P, Yu F, et al. Increased Likelihood of Glaucoma at the Same Screening Intraocular Pressure in Subjects With Pseudoexfoliation: The Thessaloniki Eye Study. Am J Ophthalmol 2009;148: 606-613.e1. https://doi.org/10.1016/j.ajo.2009.03.024

33. Topouzis F, Founti P, Yu F, Wilson MR, Coleman AL. TwelveYear Incidence and Baseline Risk Factors for Pseudoexfoliation: The Thessaloniki Eye Study (An American Ophthalmological Society Thesis). Am J Ophthalmol 2019; 206: 192-214. https://doi.org/10.1016/j.ajo.2019.05.005

34. Vijaya L, Asokan R, Panday M, Choudhari NS, Sathyamangalam R V, Velumuri L, et al. The Prevalence of Pseudoexfoliation and the Long-term Changes in Eyes With Pseudoexfoliation in a South Indian Population. J Glaucoma Glaucoma 2016; 25: e596-e602.

https://doi.org/10.1097/IJG.0000000000000276

\section{PREVALENCE OF PSEUDOEXFOLIATION SYNDROME, ITS CHANGES AND ASSOCIATIONS \\ WITH GLAUCOMA IN THE POPULATION OF KAUNAS CITY IN KAUNAS POPULATION \\ U. Rumelaitienė, M. Špečkauskas, A. Tamošiūnas, R. Radišauskas, D. Žaliūnienẻ}

Keywords: pseudoexfoliation syndrome, PEX prevalence, glaucoma.
Summary

The aim of the study to analyze the prevalence of pseudoexfoliation syndrome (PEX), it's changes and associations with glaucoma and glaucoma suspect in Kaunas.

Methods. At follow-up study (2016) 631 Kaunas resident aged 55-83 years old were examined. All study subjects underwent (1262 eyes): best corrected distant visual acuity, central corneal pachymetry, slit-lamp biomicroscopy, intraocular pressure (IOP), visual field study N-30-F, retinal optical coherent tomography, pupil diameter was measured after diagnostic midriasis, stereoscopic fundus photographs, optic nerve disk and Vertical cup/disk ratio was evaluated from fundus photos. PEX was diagnosed by slit-lamp examination, when PEX presense was confirmed in the anterior segment of the eye.

Results. PEX was diagnosed in 216 subjects, and there was no PEX in 415 subjects. The prevalence of PEX was $34.2 \%$. The biggest prevalence of PEX was in the eldest (76-83 y) group $45.3 \%$ regardless of gender. The prevalence of PEX did not differ between genders: male $-35.6 \%$ and female $-33.4 \%(\mathrm{p}>0.05)$. Glaucoma (GL) was diagnosed in 113 eyes (9.1\%) out of 1262 eyes, 63 (6.8\%) GL cases were in no PEX group vs. 50 (15.7\%) in PEX group $(p<0.001)$. After medicamental midriasis pupil diametre was significantly smaller in GL PEX group compared with No PEX group (5.1 and $6.0 \mathrm{~mm}$ accordingly; $\mathrm{p}<0.001$ ). IOP did not differ significantly in GL PEX and No PEX groups (16.0 and $15.5 \mathrm{mmHg}$ accordingly; $\mathrm{p}>0.05$ ).

Conclusion. A further spread of PS was found in the study contingent and especially in the older age group. PS has increased 3 folds in 10 years. GL was twice as common in PS group. GL was diagnosed in 113 eyes (9.1\%) out of 1262 eyes, 63 (6.8\%) GL cases were in no PEX group vs. 50 (15.7\%) in PEX group. In 10 years, 80 new GL cases have emerged. It was found that significantly lower medicamental midriasis was achieved in GL PEX subgroup compared with GL No PEX subgroup.

Correspondence to: ugne.rumelaitiene@kaunoklinikos.lt

Gauta 2021-11-06 